\title{
QUALITY HOUSE APPLICATION WITH TAKING INTO CONSIDERATION CLIENT'S SATISFACTION
}

\begin{abstract}
From an enterprise point of view global market of these days can be characterized as highly demanding and competitive, and at the same time frequently changeable. To survive on such market, enterprise needs to satisfy customers regarding the quality, price and delivery time. Quality is one of the key elements that currently affect the application of the organization in the market. Quality and its management ensuring have long ceased to be the domain of only a handful of top organizations. Paper shows the using and benefits of QFD method.
\end{abstract}

Key words: quality, satisfaction, client

\section{Introduction}

The aim of all businesses is getting a position guarantee of the market, if not the dominance on it, it is at least providing for the fill orders of calm existence. The easiest way to this is showing on the market services or products that are compatible with the expectations of customers. In this process an important role is examining expectations, as well as interpreting them and processing into features the service or the product. The method is helpful in the development of QFD also known as quality function. This method is also well-known under the name the Voice of the Customer. The method approaches a product quality in a systematic and logic way and gets translated through all product design stages: from conceptual design of the product to production stage (VEŽA G. , Grubić T. 2003, StasiaK-Betlejewska R. 2016, Allen D.R., RaO T.R, 2000, Chan, L.-W. \& WU, M.-L. 2002).

\footnotetext{
${ }^{1}$ Institute of Engineering Production, Faculty of Management, Czestochowa University of Technology, e-mail: asros@op.pl.

${ }^{2}$ Students, Faculty of Management, Czestochowa University of Technology.
} 


\section{QFD method}

A QFD method is a standard of the guidance with quality of designing standards which are being exploited in the quality (BIELAWA A., Frą́s J., GoŁęBIOWSKI M. 2006, GoŁĘBIOWSKI M., JANASZ W., ProzorowicZ M. 1999, HAMroL A. 2005) management (Fig. 1). Applying it increases the likelihood of compliance procedures and systems make to them by the management requirements. Quality Function Deployment (the expansion of a function of the quality) to understand we can as taking into account like of a lot of elements being able to influence the product quality or processes on all stages of the design (HILl N, ALEXANDER J. 2003).

In 1966 Y.Akau developed assumptions of this method. For the first time she was applied in the shipyard in Kobe in 1972 which was involved in a concern Mitsubishi. Attempts of the generalization turned up for her at 1975-1979 years by the Japanese Society of the Control with Quality. At the end of years 70. was applied in the USA for example at the establishment of Ford or General Motors, and then in such enterprises like At\&T, the Hewlett Packard, and ITT.

QFD has been used in a large number of industries, including financial services, health services and the software industry. The best known instrument of QFD is the so-called House of Quality (HoQ). Generally speaking, the HoQ is the matrix which analyzes customer requirements in detail and translates them into the developers' language. The HoQ is the framework of most of the matrices used in QFD. One important feature of QFD is the separation of customer requirement (the actual need) and technical solution (the features of the product). This is done in order to assure that the final product's features are not determined by the technically possible but by the fitness for use, i.e. the features the customers demand (ChAN, L.-W. \& WU, M.-L. 2002, KACHNIEWSKA M. 2002, ŁAŃCUCKI J. 2001, MYSZEWSKI J.M. 2005).

The starting point for the development of this method has become noticing the essence of design quality products that were produced after World War II in Japan, which replaced copyings of attractive European 
patterns with the strategy with implementing individual original solutions.

QFD method otherwise known as quality function development is very much intuitive; it doesn't contain statistics, is being expressed in the form of the fundamental list of the specification and aims of the product design. Includes extension 4 "houses" or "matrix" increasing levels of specifications (OBORA H., ĆWIKLICKI M. 2011, www.statsoft.pl/spc.htm, ŻUCHOWSKI J. 2004.).

The QFD method is helping to solve connected problems with it, that mass production or large-serial is giving little abilities of the direct contact to the enterprise with the potential consumer and what's more in the situation, while products are over and over again more technologically advanced, and apart from that are catering a lot. For example a car the Toyota or the Mercedes used mainly as the means of transport, but is also the source of pleasure or the prestige of the possession. The QFD method consists determining product features and their interrelationships, as well as guaranteeing so that all features are taken into consideration in developmental works, the production and the product itself.

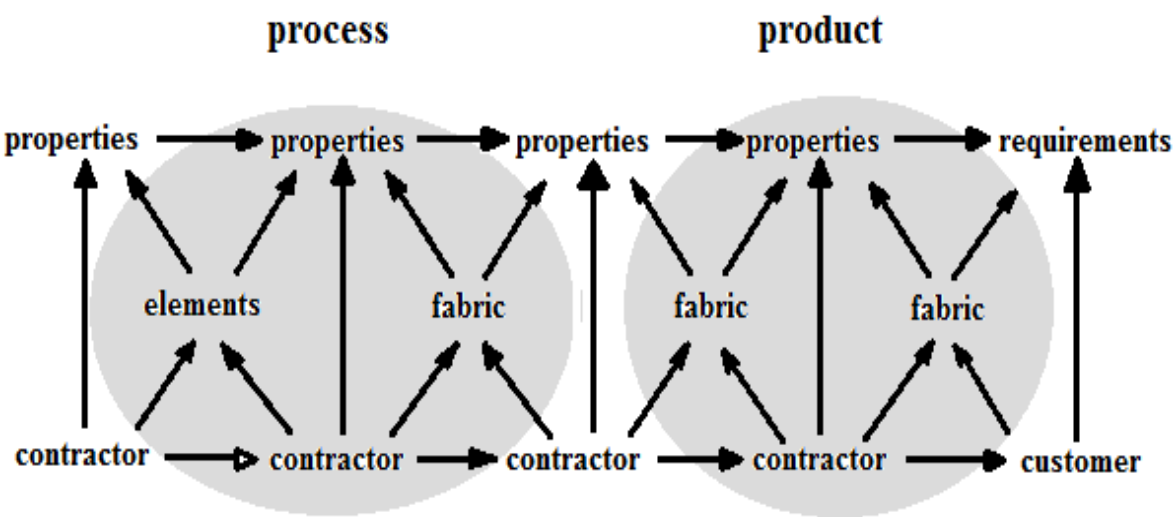

Fig. 1. Development of quality function in a broad sense.

Source: Myszewski J.M. 2009. 
Applying the QFD method is bringing 2 benefits. First is fact that needs of the consumer are written with his own words. Secondly, data are collected and analysed by cross-functional groups. An important benefit of this method is that it takes into account the voice of the customer and retains it, excluding the need for new interpretation, precluding the need for re-interpretation, as that the voice is converted to internal technical requirements, which are designed to meet the needs of the consumer. Other benefits which are possible to reach through the QFD method:

- creating an integrated organizational structure that is designed to facilitate the control of compliance with the schedule,

- embarking forms of teamwork and break down barriers between departments,

- circulation of information about requirements of the consumer through the entire structure of the company,

- effective recognizing the hierarchy of expectations of the consumer,

- possibility of predicting of the degree of fulfilling the requirements the customer,

- increasing predispositions of the enterprise for fulfilling the requirements put by the consumer,

- making right decisions based on collected information,

- preventing many costs and the waste of time.

The method of the expansion of a function of the quality consists of next stages:

- transferring features which are desired by the consumer to product features offered,

- transferring product features into building blocks of the product which are supposed to provide appearing of desired features,

- describing necessary processes for producing specific building blocks of the product, the production planning which is supposed to guarantee the incident of desired processes.

Creating the standard is a process to a large extent based on the processing of information about elements which are deciding on, whether the object will meet expectations put for him. The complexity of the designed object, as well as the search for unconventional solutions can justify the need to perform tasks in a team project. Appropriate 
composition and the labour organization of the team, as well as using appropriate methods in the team - these are elements increasing the effectiveness of using available information.

Undertaking Quality Function Deployment tasks don't have character of the casual work. It is necessary to appoint the team and to allocate due means which are supposed to ensure the success. The interdepartmental team will need about three months to complete this part of the collection of data that is needed to carry out the first level of the matrix sheet. Training the team is needed. It takes about five working days that are scattered during the first month of work. It should also provide explanations management representatives and others that are associated with the project, to understand its purposes. Too detailed sheet matrix, can lead to misunderstandings and disputes about details. It is recommended to classify expectations logically arranged nodes to make works smaller to manageable sizes. It is easy to fall into the trap which consists in seeking the appropriate sheet of the matrix, while the more important thing is to understand the process, as well as his final objectives in drawing up the own sheet which will be fit the creativity to the type of the business activity of the company. Between characteristics of the product ("How") it is necessary to keep its balance in order to achieve competitive optimal benefits. Keep the one hand, balance between the realism, but permanent improving on the other.

The QFD method isn't only a task for designers. It is necessary to involve services of marketing and the production in the process. The market is still changing, even during the design cycle, especially when it is long. The production process is the ultimate test of all pre-production work. It should be on guard against the risk of accidental confusion of "How" of "What".

QFD team have to answer the three key questions:

1 Who is our customer?

2. what is desire of the customer?

3. how to fulfil the need of the customer?

In response to these supporting questions are questionnaire forms, questionnaires, interviews with customers, experience and the knowledge of team members. Determinants: who, how, what input to the QFD 
Zeszyty Naukowe

No. 2(5)

Quality. Production. Improvement

2016

pp. $45-55$

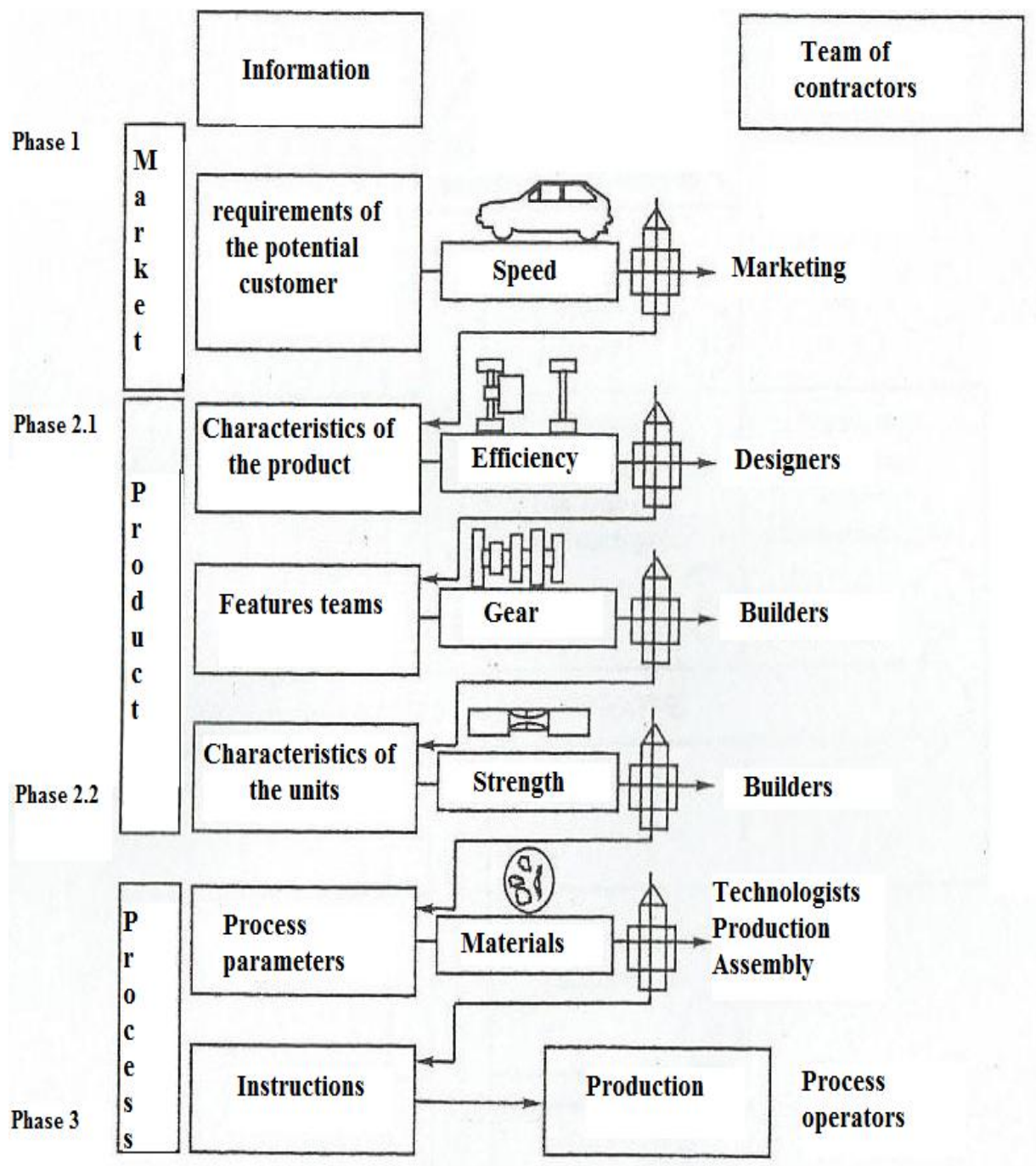

Fig. 2. QFD application phase methods (for example, automotive drive system).

Source: Hamrol A. 2005 
matrix or the net of the house of the quality which belongs to straights of boards qualities. Variables in columns, and what is being put in rows. The scope of this method includes market research, developmental designing new concepts, invention, testing prototypes and an end product, services after the sale, as well as searching and the debugging.

\section{The scheme of the QFD Method}

The scheme of the QFD Method consists of the following steps:

1. Recognizing the structure of the quality appropriately designed system ( $Q D$ or development of quality - to define the quality of the final product designed by transforming the user's requirements with appropriate characteristics (qualitative) and the systematic development of relations with the quality of the relevant characteristics of each part, each functional component, and each element of the process. 14) and of planned process (in narrow QFD meaning). In this phase establishes a set of expectations that are placed on the object by its consumer properties of an object affect the ability to meet these expectations, and are defined by the designer object. It is indicated verification of the relationship between properties and ability to achieve the object individual expectations.

2. Determining the degree of measures of the quality. The matrix diagram of the relation is crowning the research on the structure of the quality of the object. It is record of the state of the knowledge about the system: of expectations and their priorities (voice of the customer), structures and strength of connections between expectations and properties, of resulting ranking indicating properties what one should attract the attention of the object in the design and the realization of object.

3. Analysis and the selection of the property about key ranks - with purpose of providing them with the supervision in the implementation process and designing the object. Analysis and selection of factors about key ranks are an activity which is being carried out all along the way as well as constitutes the illustration of Pareto analysis. This 
phase enables to hold on to the "mainstream" in the course of the design.

\section{Quality house}

The house of the Quality is a method of transferring needs and requirements of recipients into characteristics of the product or the service (Fig. 3).

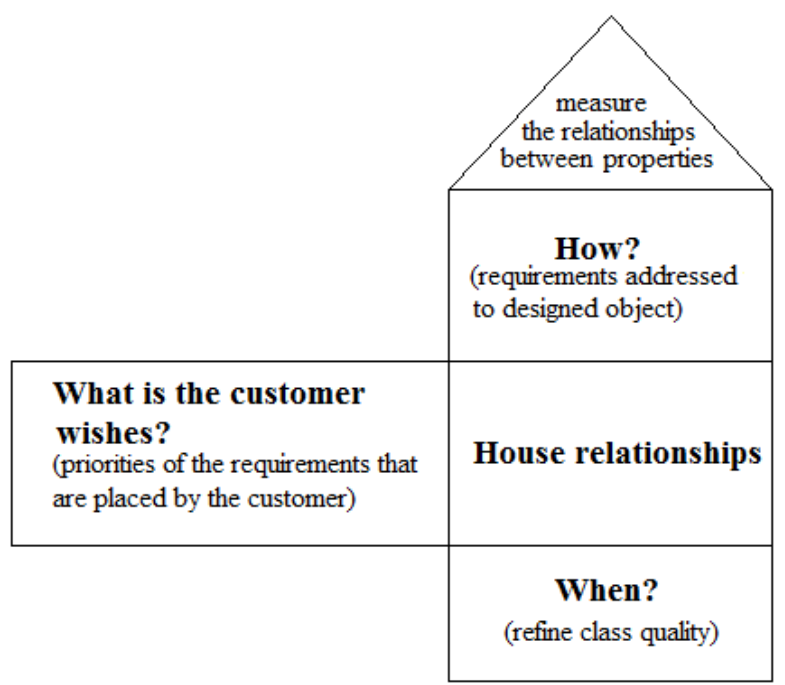

Source: own study

Fig. 3. Scheme House of Quality.

Growing pressures on minimizing costs of the design and shortening the time of lasting him caused that a need to create the method, enabling to transfer unconscious and the conscious consumer expectations to technical parameters with simultaneous taking into account technological possibilities, the degree of the importance of individual features, as well as relationships between them. The QFD method became an answer to this need. The House of Quality allows among others on: creating the homogeneous organizational structure, breaking barriers between 
departments, circulation of information about requirements of the customer, making correct decisions based on the accumulated knowledge, as well as avoiding the waste of time and many costs.

Quality function deployment method allow you to get the answer, what is the structure of the quality of the proposed facility, in particular, what the priorities should be followed when determining the appropriate values for its properties. The method is based for establishing the list of requirements and recognizing the list of properties of the object which are connected with the ability of the object for carrying these expectations out. The rank of every property is specific on the basis of assessment of strength of the relation between this property and with individual expectations and based on priorities which are assigned to these expectations. The attention of designers is being pointed to issues about the key importance for the realization of expectations through the modeled object. Sets of different kind of techniques of the team work which are using the graphical presentation of information, and are also facilitating the communication in the team, applying this method and are helping to describe the structure of the object, as well as information to his subject.

\section{Summary}

By using this process it is ensured that problems related to the product from the customers' point of view will be detected. Although the method has proved to be very efficient in detecting product related problems it suggests no solutions for those problems.

Analysis of issues related to the quality of the house leads to the conclusion that by using the method of QFD can get the answer, what is the structure of the quality of the proposed facility, and in particular what should guide priorities in determining appropriate values for its properties.

QFD provides a system of comprehensive development process for: 
- Understanding 'true' customer needs from the customer's perspective.

- What 'value' means to the customer, from the customer's perspective.

- Understanding how customers or end users become interested, choose, and are satisfied.

- Analyzing how do we know the needs of the customer.

- Deciding what features to include.

- Determining what level of performance to deliver.

- Intelligently linking the needs of the customer with design, development, engineering, manufacturing, and service functions.

The QFD methodology can be used for both tangible products and non-tangible services, including manufactured goods, service industry, software products, IT projects, business process development, government, healthcare, environmental initiatives, and many other applications.

QFD method is not difficult to use, provides a very effective way using inputs of customer (ideas, concepts, various ways to increase the utility value of the product). Subsequently the use of inputs so that it can be created the most successful output, which is focused on the customer and ensuring their satisfaction. It focuses on the most important quality characteristics which must be improved, provides a process for defining tasks for enhancing the competitiveness of the product (ŠOLC M. 2013.).

\section{Bibliography}

1. Allen D.R., RAO T.R, 2000. Analysis of customer satisfaction data, ASQ Quality Press.

2. BIElawa A., Frąís J., GOŁęBIOWSKI M. 2006. Podstawy zarządzania jakościa $w$ przedsiębiorstwie, Wydawnictwo Naukowe Uniwersytetu Szczecińskiego, Szczecin.

3. CHAN, L.-W. \& WU, M.-L. 2002. Quality function deployment - A literature review. European Journal of Operational Research, 143, 463-497. 
4. GoŁęBIOWSKI M., JANASZ W., ProzorowiCZ M. 1999. Zarzadzanie jakościa $w$ przedsiębiorstwie, Wydawnictwo Naukowe Uniwersytetu Szczecińskiego, Szczecin.

5. HAMROL A. 2005. Zarządzanie jakościa z przykładami, Wydawnictwo Naukowe PWN, Warszawa.

6. Hill N, Alexander J., 2003. Pomiar satysfakcji $i$ lojalności klientów, Oficyna ekonomiczna.

7. KACHNIEWSKA M. 2002. Zarządzanie jakościa usług turystycznych, Difin, Warszawa.

8. ŁAŃCUCKI J. 2001. Podstawy Kompleksowego Zarządzania Jakościa TQM , Wydawnictwo Akademii Ekonomicznej, Poznań.

9. MYSZEWSKI J.M. 2005. Po prostu jakość Podręcznik zarzadzania jakościa, Wydawnictwo Wyższej Szkoły Przedsiębiorczości i Zarządzania im. Leona Koźmińskiego, Warszawa 2005.

10. OBORA H., ĆWIKLICKI M. 2011. Hoshin kanri Japońska metoda strategicznego zarzadzania jakościa w Polsce, Polskie Wydawnictwo Ekonomiczne, Warszawa.

11. ŠolC M. 2013. QFD Method - One of the Tools of Quality Management, Electronic International Interdisciplinary Conference, Industrial and Civil Engineering, pp. 459, 466.

12. VEŽA G. , GRUBIĆ T. 2003. Application Of The Quality Function Deployment - Qfd Method In A Product Design Stage, $2^{\text {nd }}$ Daaam International Conference On Advanced Technologies For Developing Countries.

13. www.statsoft.pl/spc.htm

14. ŻUCHOWSKI J. 2004. Narzędzia i metody doskonalenia jakości, Politechnika Radomska, Radom.

15. StASIAK-BETLEJEWSKA R. 2016. The Wooden Furniture Product Value Creating with QFD Method Applying. Croatian Quality Managers Society / Hrvatsko Drustvo Menadzera Kvalitete, 17th International Symposium on Quality. Quality Makes a Difference, Zadar, Chorwacja, pp. 393- 414. 